\title{
The Study of the Social Cost in Construction Projects Bidding
}

\author{
Qi WANG, Huachao QIAN* \\ Nanjing Forestry University, Nanjing, Jiangsu, China
}

\begin{abstract}
As the perfect effective means that makes social resource reasonable disposition and reduces social production cost and perfects market trade rule. but high social comes into being in the process of bidding. And mathematical model of social cost of bidding is set up through mathematics method to analysis the Social Cost in Construction Project Bidding and the ways to reduce the Social Cost in Construction Project Bidding.
\end{abstract}

KEYWORDS: engineering project; bidding; Social Cost

\section{INTRODUCTION}

In 1929, the French economist simmons first put forward the concept of social cost [1]. Social cost refers to the causes that made by oneself but the others have to assume the economic or other aspects of the consequences [2]. The social cost of the bidding for engineering projects is the sum of every tangible and intangible costs such as the fund, energy, human input, resource and time that both sides of the bidding and relevant government agency need to pay to ensure the smooth implementation of construction project activity.

At present, the studies of the bidding are mainly focus on the choice of bidding strategy, the choice of the ways of bidding, how to effectively guarantee the fair and justice of bidding, how to improve the system of bidding and so on. There are few researches about the social cost of the bidding. For instance, Zhang ying analyzed the bidding mechanism in an economic perspective [3]. Zheng yu studied the social cost of the bidding for Chinese construct project in his dissertation [4]. And the studies of the ways to reduce social costs of project bidding are few. Based on the above analysis, this paper is mainly about the ways to reduce the social cost of bidding combined with the compositions and sources of the social cost.

\section{SOCIAL COST OF THE BIDDING FOR ENGINEERING PROJECTS}

\subsection{The meaning of Social cost of the bidding for engineering projects}

The social cost of the bidding for engineering projects is the sum of every tangible and intangible costs that both sides of the bidding and relevant government agencies need to pay to ensure the success of the projects.

\subsection{The composition of Social cost of the bidding for engineering projects}

The composition of the social cost contains two parts, transaction cost and institutional cost. Figure 1 describes the division and composition of the social cost of bidding for construct projects.

One part of the social cost is to ensure the smooth implementation of every link of bidding behavior, and this is called necessary social cost. Another part of the social cost is not as necessities a normal project bidding behavior need to spend, which is called invalid social costs [5].

From the current situation of the construction market in China, the social cost of engineering project bidding is mainly composed of the following costs.

1. Service charge of bidding agent: Refers to the cost that the tenderer entrust a bidding agency to preparing bidding document, reviewing the bidder qualifications, organizing bidders to the scene and answering questions, organize bid opening, evaluation and selection, providing the cost that 
previous consulting, coordination of the contract is needed.

2. Service charge of construction engineering trading: Refers to the service charge that are provided by the counterparties to service both parties to the relevant provisions.

3. The tender documents fee: Refers to the fees that the tendering units pay to the bidding agency.

4. The tendering units bidding fee: Refers to the fees that tendering units pays for the project bidding activities. Including:

(1)Cost of making bidding document.

(2)Cost of sales staff, for example: Wages, welfare, the winning project commission, travel expense and so on.
(3)Intermediary fee: Refers to the fees that and paid for a third party when tendering units is introduced through a third party, and bidding with the aid of a third party relationship.

(4)Rent-seeking cost: Refers to the fees that the tendering units paid to the power party to get the engineering project through bribery and social engagement.

(5)Bidding collusion cost: The tendering units together with the other companies to win the bidding illegally.

Above are some common charges, seeing from the tendering market now, the social cost of bidding are far from above.

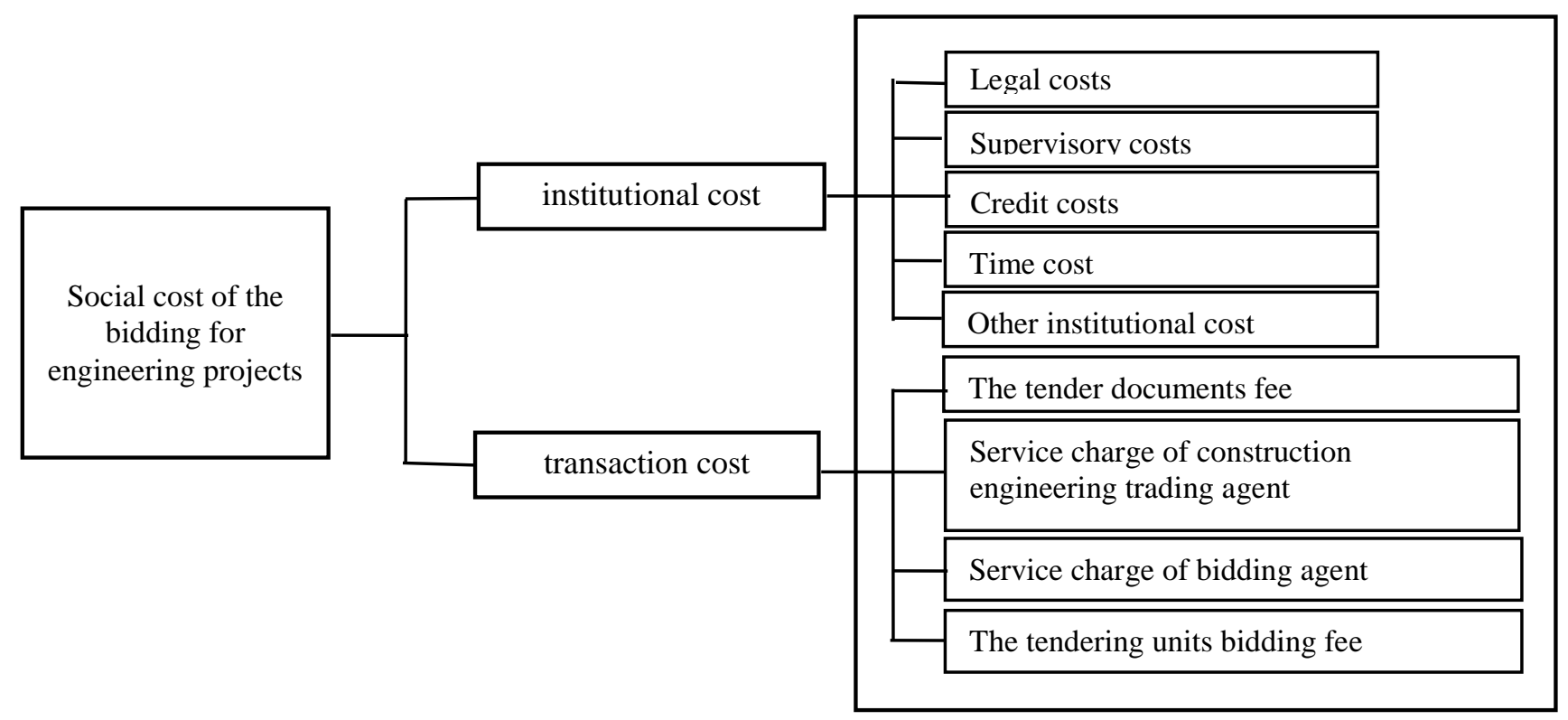

Figure 1 The division and composition of the social cost of bidding for construct projects

\section{THE MATHEMATICAL MODEL OF SOCIAL COST FOR ENGINEERING PROJECT BIDDING SOCIAL COSTS}

Known from the consists of the social cost, it concludes service charge of bidding agent, service charge of construction engineering trading, the tender documents fee, the tendering units bidding fee and so on, Here we mainly analysis the cost of necessary social cost.

1. Use $X_{1}$ represents service charge of bidding agent. For engineering project bidding, according to the provisions in<The measures for bidding agent service charge management $>$, the relationship between service charge of bidding agent and engineering investment can be described as follows:

$$
x_{1}=k_{1}+k_{2} P
$$

Among them: $\mathrm{P}$-Engineering investment;

$$
\mathrm{k}_{1}, \quad \mathrm{k}_{2} \text {-According to the }
$$

provisions in $<$ The measures for bidding agent service charge management $>$, calculate the coefficient of service charge of bidding agent. $\mathrm{K}_{1}$ increases with the increase of $\mathrm{P}$, while $\mathrm{k}_{2}$ decreases with the increase of $\mathrm{P}$.

2. Use $x_{2}$ represents service charge of construction engineering trading. For construction projects, in the same way:

$x_{2}=k_{3}+k_{4} P$

Among them: $\mathrm{P}$-Engineering investment;

$\mathrm{k}_{3}, \mathrm{k}_{4}$-According to the provincial regulations on service charge of construction engineering trading charging standard, calculate the coefficient of service charge of construction engineering trading, $\mathrm{k}_{3}$ increases with the increase of $\mathrm{P}$, while $\mathrm{k}_{4}$ decreases with the increase of $\mathrm{P}$.

3 . Use $x_{3}$ represents the tender documents fee. This part ranges in a small scale, We can approximately take it as $A_{1}$, that is:

$x_{3}=A_{1}$

4. According to consists of social cost of bidding, The tendering units bidding fee refers to all of the 
cost that happened during the bidding activities. Among them, cost of making bidding document. cost of sales staff, intermediary fee are normal spending, we call it a reasonable bidding cost. Rentseeking cost and bidding collusion cost etc. all belong to abnormal expenditure, we call this kind of cost is unreasonable bid cost.

Use $x_{4}$ represents the tendering units bidding fee, $x_{4}$ increases with the increase of $\mathrm{P}$, But the bigger the engineering investment is, the slower the $x_{4}$ 's increasing speed is. The relationship between $x_{4}$ and $\mathrm{P}$ is similar to exponential function: $y=x^{t}(0<\mathrm{t}<1)$

$$
\boldsymbol{x}_{4}=\boldsymbol{k}_{5} \boldsymbol{P}^{t}
$$

Among them: $\mathrm{k}_{5}$ - Correction coefficient;

$\mathrm{t}$ - The index related to tendering units bidding costs and the engineering investment.

5. Use $\mathrm{C}$ represents the social cost of bidding, The tenderers participate in the bid are n, If the investment of a project is $\mathrm{P}$, The social cost of winning unit are as follows:

$$
C=x_{1}+x_{2}+x_{3}+x_{4}
$$

Put the type (1), type (2), type (3), type (4) into the formula above, we can get:

$$
C=k_{1}+k_{2} P+k_{3}+k_{4} P+A_{1}+k_{5} P^{t}
$$

The social cost of this project is:

$$
C_{n}=x_{1}+x_{2}+n x_{3}+n x_{4}
$$

Put the type (1), type (2), type (3), type (4) into the type(7), we can get:

$$
C_{n}=k_{1}+k_{2} P+k_{3}+k_{4} P+n A_{1}+n k_{5} P^{t}
$$

\section{CONCLUSION}

Seeing from the formula

$C_{n}=k_{1}+k_{2} P+k_{3}+k_{4} P+n A_{1}+n k_{5} P^{t}$, we can use the following ways to reduce social cost.

\subsection{Control of the number of tendering units reasonably}

To control the number of bidding units, the tenderer should choose different ways of bidding according to the different investment scale. For projects that scale is small, they can choose selective tendering. For some tiny projects, they can directly entrust a capable company to attend the project. Only for the big or special projects, they should choose open tendering, and must control the number of tendering units.

\subsection{Decrease $A_{1}$}

Decrease $A_{1}$, that is, reduce the tender documents cost, the most effective way is to standardize the cost of tender documents. Because there is no universally accepted standard, generally determined by the bid invitation unit, it is only through the actual situation around to make the rules for the corresponding specification.

\subsection{Decrease $n k_{5} P^{t}$, decrease the cost of the tendering units}

\subsubsection{Necessary social cost}

From the tender side, to reduce the cost of the tender bidding strategy, we must focus on the full estimated cost of the tender, choose the best tender and improve the successful rate. The purpose of the tender is to obtain the right to build the project, but sometimes inevitable with blindness, there are marked on the cast, aimlessly. Therefore, to make the bidding proces, we must have a clear purpose and principles of the bid, the only way to improve the input-output ratio of the bidding is to achieve better results. We should take feasibility and possibility of the project into consideration when we select the project.

\subsubsection{Unnecessary social cost}

Through legislation to regulate the tenderer or bid's behavior for obtaining engineering contract without legal bid. Solute the conflict between the laws and regulations legislation, such as law enforcement, confusion and unnecessary legal costs. Prevent the extra credit cost that caused by one side providing false materials to the other side. Prevent the excessive competition among large bidders, etc.

\section{REFERENCES}

[1] Flanagan, R. and Norman, G. (1985). "Sealed bid auctions: an application to the building industry." Constr. Manage. Econ. 3, 145-161. 9lu.

[2] Liu jie, Lu hui min. The analysis of social cost for engineering construction bidding. Construction management modernization, 2007(2):54-56.

[3] Zhang ying. Economic analysis of bidding mechanism. China's bidding. 2006 (41).

[4] Zheng yu. The study of social cost for construct project. Jiangsu: Southeast university, 2006

[5] Rowlinson, S. M., and Walker, A. (1995). The construction industry in hongkong, Longman Hong Kong, Hong Kong. 